\title{
PENINGKATAN PRESTASI BELAJAR SISWA DALAM PEMBELAJARAN IPA MATERI BUNYI DENGAN MENERAPKAN METODE KOOPERATIF MODEL JIGSAW DI KELAS VIII A SMP NEGERI 2 KWADUNGAN TAHUN PELAJARAN 2013/2014
}

\author{
Dwi Retno Wahyuni \\ SMP Negeri 2 Kwadungan, Ngawi \\ Email: dwiretnowahyuni7@gmail.com \\ Diterima 23 Desember 2014 disetujui 12 Februari 2015
}

\begin{abstract}
This study aimed to increase student achievement in science learning material by applying sound Jigsaw model of cooperative methods in class VIIIA of SMP Negeri 2 Kwadungan school year 2013/2014 . Research using classroom action research ( PTK ) includes planning, action, observation, and reflection. The research instrument used syllabus, lesson plans, student activity sheets, observation sheets, and test. Data retrieval learning achievement tests and observations were performed every cycle. The results showed that students mastery of classical first cycle of $60 \%, 87.5 \%$ second cycle. show enthusiastic learn. Observations show their courage students to ask and answer questions discussion. The results showed that sound science learning material with the application of Jigsaw model of cooperative methods can improve student achievement .
\end{abstract}

Keywords : learning achievement, jigsaw, communicate

\section{PEDAHULUAN}

Ilmu Pengetahuan Alam (IPA) atau sains pada hakekatnya merupakan pengetahuan yang berdasarkan fakta, hasil pemikiran para ahli dan hasilhasil eksperimen yang dilakukan para ahli. Memahami IPA tidak semata-mata menghafal fakta-fakta, tetapi juga belajar mengadaptasikan prinsip-prinsip dasar IPA ke dalam penerapan sehari-hari, hal ini tidak hanya membantu siswa menghubungkan IPA dengan dunia mereka sehari-hari, melainkan juga membantu siswa untuk membentuk keterampilan-keterampilan yang akan menjadikan mereka pengambil keputusan yang bertanggung jawab dan pemikir yang kritis (Nur, 1998).

Berhasilnya tujuan pembelajaran ditentukan oleh banyak faktor diantaranya adalah faktor guru dalam melaksanakan proses belajar mengajar, karena guru secara langsung dapat mempengaruhi, membina dan meningkatkan kecerdasan serta keterampilan siswa. Peran guru sangat besar dalam menentukan keberhasilan proses pembelajaran, selain itu tujuan pendidikan dapat berhasil secara maksimal sangat penting. Guru diharapkan memiliki cara/model mengajar yang baik dan mampu memilih model pembelajaran yang tepat dan sesuai dengan konsep-konsep mata pelajaran yang akan disampaikan. Cara/ model mengajar yang kreatif dan inovatif sangat diperlukan dalam mengarahkan siswa, sehingga siswa dapat memahami konsep-konsep IPA lebih mendalam.

Kegiatan pembelajaran yang dilakukan oleh guru IPA masih belum banyak mengeksplorasi kemampuan siswa. Kemampuan IPA tidak cukup dikemas dengan pembelajaran hafalan. Guru masih banyak mengajarkan konsep-konsep yang hanya sebatas dihafalkan oleh siswa. Berdasarkan permasalahan yang dihadapi, maka diperlukan pemikiran-pemikiran dan tindakan-tindakan agar siswa tidak mengalami kesulitan dalam mempelajari konsep-konsep IPA, sehingga tujuan pembelajaran dapat tercapai dengan baik dan hasilnya dapat memuaskan semua pihak. Penggunaan metode pembelajaran yang dapat meningkatkan pemahaman konsep dan kreativitas dirasa sangat penting untuk membantu siswa dalam memahami 
konsep-konsep IPA.

Materi IPA kelas VIII semester genap mengenai "bunyi" merupakan sebuah materi IPA yang memerlukan eksplorasi siswa, tidak sebatas menghafal. Konsep tentang "bunyi" memerlukan setting pembelajaran yang dapat mengeksplorasi siswa, sehingga memerlukan model pembelajaran dengan eksperimen. Situasi dan kondisi di SMPN 2 Kwadungan Ngawi belum sepenuhnya tercukupi adanya alat dan bahan untuk kegiatan percobaan, sehingga diperlukan disain pembelajaran yang dapat meningkatkan pemahaman konsep siswa meskipun tidak harus menggunakan kegiatan eksperimen di laboratorium. Kegiatan belajar mengajar dikemas sedemikian rupa, sehingga siswa tidak bosan menerima muatan informasi, dan materi dapat terserap dengan baik.

Kegiatan belajar mengajar sebaiknya lebih mempertimbangkan kebutuhan siswa. Siswa tidak hanya menerima muatanmuatan informasi dari guru, tapi siswa juga dapat saling bertukar informasi dari sesama siswa. Sistem pengajaran yang diperlukan dalam hal ini adalah sistem pengajaran yang memberi kesempatan kepada anak didik untuk bekerja sama dengan sesama siswa dalam tugas-tugas terstruktur. Sistem pembelajaran demikian ini dikenal dengan sistem "pembelajaran gotong royong" atau cooperative learning. Pembelajaran cooperative learning guru bertindak sebagai fasilitator. Sistem pembelajaran cooperative learning bukan sekedar kerja kelompok, melainkan penstrukturan.

Pembelajaran kooperatif adalah suatu metode pembelajaran dengan cara mengelompokkan siswa ke dalam kelompok-kelompok kecil untuk bekerja sama dalam memecahkan masalah. Kemampuan siswa dalam setiap kelompok adalah heterogen. Sistem pembelajaran cooperative learning dapat didefinisikan sebagai kerja/ belajar kelompok yang terstruktur. Terdapat lima unsur pokok dalam belajar terstruktur, yaitu: 1) saling ketergantungan positif, 2) tanggung jawab individual, 3) interaksi personal, 4) keahlian bekerjasama, dan 5) proses kelompok. Salah satu model pembelajaran kooperatif adalah model pembelajaran jigsaw.

Model jigsaw dikembangkan oleh Elliot Aronson dan kawan-kawannya dari Universitas Texas dan kemudian diadaptasi oleh Slavin dan kawan-kawannya. Metode jigsaw kelas dibagi menjadi beberapa tim yang anggotanya terdiri dari 4 - 6 siswa dengan karakteristik yang heterogen. Bahan akademik disajikan kepada siswa dalam bentuk teks; dan tiap siswa bertanggung jawab untuk mempelajari suatu bagian dari bahan akademik tersebut. Anggota dari berbagai tim yang berbeda memiliki tanggung jawab untuk mempelajari suatu bagian akademik yang sama dan selanjutnya berkumpul untuk saling membantu mengkaji bagian bahan tersebut. Kumpulan siswa semacam itu desebut "kelompok pakar" (expert group). Para pakar siswa yang berada dalam kelompok pakar kembali ke kelompoknya semula (home teams) untuk mengajar anggota lain mengenai materi yang telah dipelajari dalam kelompok pakar. Setelah diadakan pertemuan dan diskusi dalam "home teams", para siswa dievaluasi secara individual mengenai bahan yang telah dipelajari. Dalam metode Jigsaw versi Slavin. Individu atau tim yang memperoleh skor tinggi diberi penghargaan oleh guru.

Sintaks strategi pembelajaran kooperatif tipe jigsaw (Susilo, 2009)

1. Guru membagi peserta didik dalam kelompok

2. Tiap peserta didik dalam kelompok diberi bagian materi yang berbeda (kelompok asal)

3. Tiap peserta didik dalam kleompok membaca bagian materi yang ditugaskan

4. Anggota dari kelompok berbeda yang telah mempelajari bagian/ subbab yang sama bertemu dalam kelompok baru (kelompok ahli) untuk mendiskusikan subbab mereka

5. Setelah selesai diskusi dalam kelompok ahli, setiap peserta didik kembali ke kelompok asal dan bergantian mengajar teman satu kelompok mereka tentang subbab yang mereka kuasai. Sementara itu, tiap anggota lainnya mendengarkan 
dengan sungguh-sungguh, kemudian membuat rangkuman

6. Tiap kelompok atau tim ahli mempresentasikan hasil diskusi

7. Guru dan peserta didik membuat kesimpulan

8. Guru memberi evaluasi

Tujuan penelitian ini adalah mengetahui peningkatan prestasi belajar siswa dalam pembelajaran IPA pada materi bunyi dengan menerapkan metode kooperatif model jigsaw di kelas VIII-A SMP Negeri 2 Kwadungan tahun pelajaran 2013/2014. Hasil belajar mempunyai hubungan erat dengan prestasi belajar. Pencapaian hasil belajar dapat diketahui dengan megadakan penilaian tes hasil belajar. Penilaian diadakan untuk mengetahui sejauhmana siswa telahberhasil mengikuti pelajaran yang diberikan oleh guru. Guru dapat mengetahui sejauh mana keberhasilan guru dalam proses belajar mengajar di sekolah. Prestasi belajar IPA adalah nilai yang dipreoleh siswa setelah melibatkan secara langsung/aktif seluruh potensi yang dimilikinya baik aspek kognitif (pengetahuan), afektif (sikap) dan psikomotor (keterampilan) dalam proses belajar mengajar IPA.

\section{METODE}

Jenis penelitian yang dipilih, yaitu penelitian tindakan, maka penelitian ini menggunakan model penelitian tindakan dari Kemmis dan Taggart (dalam Sugiarti, 1997), yaitu berbentuk spiral dari sklus yang satu ke siklus yang berikutnya. Setiap siklus meliputi planning (rencana), action (tindakan), observation (pengamatan), dan reflection (refleksi). Langkah pada siklus berikutnya adalah perncanaan yang sudah direvisi, tindakan, pengamatan, dan refleksi. Instrumen yang digunakan dalam penelitian ini terdiri dari: 1) silabus, 2) rencana pelajaran (RP), 3) lembar kegiatan siswa. Lembar kegaian ini yang dipergunakan siswa untuk membantu proses pengumpulan data hasil eksperimen, 4) lembar observasi kegiatan belajar mengajar, lembar observasi aktivitas siswa untuk mengamati aktivitas siswa selama proses pembelajaran. 5. Tes formatif, tes formatif disusun berdasarkan tujuan pembelajaran yang akan dicapai. Tes formatif ini diberikan setiap akhir putaran. Bentuk soal yang diberikan adalah pilihan ganda (objektif). Yang sesuai dengan materi atau pokok bahasan dalam pembelajaran.

Indikator yang diobservasi sebanyak 4 hal yang berkaitan dengan kegiatan siswa selama KBM berlangsung. Indikator pada saat observasi kegiatan siswa terdapat pada Tabel 1.

Tabel 1. Indikator Lembar Observasi

\begin{tabular}{cl}
\hline No & \multicolumn{1}{c}{ Indikator Pengamatan } \\
\hline 1 & $\begin{array}{l}\text { Ketrampilan menemukan sendiri } \\
\text { pengetahuan atau konsep melalui } \\
\text { berbagi sumber buku }\end{array}$ \\
2 & $\begin{array}{l}\text { Keberanian bertanya sebagai } \\
\text { wujud kemauan berpikir } \\
\text { untuk mengkonstruksikan } \\
\text { konsep/ pengetahuan }\end{array}$ \\
3 & $\begin{array}{l}\text { Kerjasama dalam kelompok untuk } \\
\text { menemukan konsep/ pengetahuan } \\
\text { Ketrampilan mengkomuni- } \\
\text { kasikan secara lisan }\end{array}$ \\
\hline
\end{tabular}
adalah :

Cara penskoran pada setiap indikator

Skor $1=$ kurang,

Skor 2 = cukup,

Skor $3=$ baik

Data-data dalam penelitian ini diperoleh melalui observasi aktivitas siswa dan tes formatif. Analisis data dihitung dengan menggunakan statistik sederhana yaitu:

1. Penilaian ulangan atau tes formatif

Peneliti melakukan penjumlahan nilai yang diperoleh siswa, yang selanjutnya dibagi dengan jumlah siswa yang ada di kelas tersebut sehingga diperoleh rata-rata tes formatif dapat dirumuskan:

$$
\begin{array}{ll} 
& \bar{X}=\frac{\sum X}{\sum N} \\
\bar{X} & =\text { Nilai rata-rata } \\
\Sigma \mathrm{X} & =\text { Jumlah semua nilai siswa } \\
\Sigma \mathrm{N} & =\text { Jumlah siswa }
\end{array}
$$

\section{Ketuntasan belajar}

Ada dua kategori ketuntasan belajar 
yaitu secara perorangan dan secara klasikal. Berdasarkan petunjuk pelaksanaan belajar mengajar kurikulum 1994 (Depdikbud, 1994), yaitu seorang siswa telah tuntas belajar bila telah mencapai skor $65 \%$ atau nilai 65 , dan kelas disebut tuntas belajar bila di kelas tersebut terdapat $85 \%$ yang telah mencapai daya serap lebih dari sama dengan $65 \%$. Untuk menghitung persentase ketuntasan belajar digunakan rumus sebagai berikut.

\section{HASIL DAN PEMBAHASAN}

Data penelitian yang diperoleh berupa pengamatan aktivitas siswa pada proses pembelajaran, dan data tes formatif siswa pada setiap siklus.

Hasil pada siklus I diperoleh data bahwa hasil tes formatif menunjukan nilai rata-rata prestasi belajar siswa adalah 65,2 dan ketuntasan belajar mencapai $60 \%$ atau ada 15 siswa dari 25 siswa sudah tuntas belajar. Hasil tersebut menunjukkan bahwa pada siklus pertama secara klasikal siswa belum tuntas belajar, karena siswa yang memperoleh nilai 65 hanya sebesar $60 \%$ lebih kecil dari presentase ketuntasan yang dikehendaki yaitu sebesar $85 \%$. Hal ini disebabkan karena siswa banyak yang merasa asing dan bingung dengan metode pembelajaran yang dilakukan oleh guru. Aktifitas belajar siswa menunjukkan bahwa siswa pada dasarnya sudah terbiasa kerjasama dalam kelompok, meskipun keberanian bertanya masih kurang.

Hasil Siklus II diperoleh data bahwa hasil tes formatif diperoleh nilai rata-rata prestasi belajar siswa adalah 73,6 dan ketuntasan belajar mencapai $87,5 \%$ atau ada 21 siswa dari 25 siswa sudah tuntas belajar. Hasil tersebut menunjukkan bahwa pada siklus kedua secara klasikal siswa sudah tuntas belajar, karena siswa yang memperoleh nilai 65 hanya sebesar $87,5 \%$ lebih besar dari presentase ketuntasan yang dikehendaki yaitu sebesar $85 \%$. Selama pembelajaran siklus II, siswa menunjukkan antusias belajar. Siswa bersungguhsungguh menemukan konsep/pengetahuan dengan membawa berbagai sumber buku. Siswa juga sudah menunjukkan adanya keberanian bertanya, tetapi untuk mengkomunikasikan hasil diskusi belum ada peningkatan.

Berdasarkan hasil penelitian menunjukkan bahwa pembelajaran dengan model jigsaw materi bunyi memiliki dampak positif dalam meningkatkan prestasi belajar siswa. Hal ini dapat dilihat dari semakin mantapnya pemahaman siswa terhadap materi yang disampaikan guru (ketuntasan belajar meningkat dari siklus I, dan II) yaitu masing-masing 60\% dan $87,5 \%$. Ketuntasan belajar meningkat pada siklus pertama ke siklus kedua ketuntasan belajar siswa secara klasikal telah tercapai. Aktivitas siswa dalam proses pembelajaran dengan model jigsaw pada materi "bunyi" dalam siklus II mengalami peningkatan. Hal ini berdampak positif terhadap prestasi belajar siswa yaitu dapat ditunjukkan dengan peningkatannya nilai rata-rata siswa pada siklus II.

\section{SIMPULAN}

Hasil kegiatan pelajaran yang telah dilakukan selama dua siklus, dan berdasarkan seluruh pembahasan serta analisis yang telah dilakukan dapat disimpulkan sebagai berikut.

1. Pembelajaran dengan model jigsaw pada materi pelajaran memiliki dampak positif dalam meningkatkan prestasi belajar siswa yang ditandai dengan peningkatan ketuntasan belajar siswa setiap siklus, yaitu siklus I (60\%), siklus II $(87,5 \%)$.

2. Penerapan pembelajaran dengan model jigsaw pada materi bunyi cukup efektif, Hal ini ditunjukan dari aktivitas siswa pada siklus II, yaitu siswa bersungguh-sungguh menemukan konsep/ pengetahuan dengan membawa berbagai sumber buku dan sudah berani bertanya.

Saran

Berdasarkan hasil penelitian yang diperoleh dari uraian sebelumnya agar proses belajar mengajar IPA lebih efektif dan lebih memberikan hasil yang optimal bagi siswa maka disampaikan saran sebagai berikut. 
1. Untuk melaksanakan pembelajaran dengan model Jigsaw memerlukan persiapan yang cukup matang, sehingga guru harus mampu menentukan atau memilih topik yang benar-benar bisa diterapkan dengan pembelajaran dengan model Jigsaw pada materi pelajaran proses belajar mengajar sehingga diperoleh hasil yang optimal.

2. Dalam rangka meningkatkan prestasi belajar siswa, guru hendaknya lebih sering melatih siswa dengan kegiatan penemuan, walau dalam taraf yang sederhana, dimana siswa nantinya dapat menemukan pengetahuan baru, memperoleh konsep dan keterampilan, sehingga siswa berhasil atau mampu memecahkan masalah-masalah yang dihadapinya.

3. Perlu adanya penelitian yang lebih lanjut, karena hasil penelitian ini hanya dilakukan di kelas VIII A tahun pelajaran 2013/2014.

\section{DAFTAR PUSTAKA}

Dikmenum 1993. Petunjuk Pelaksanaan Proses Belajar Mengajar SLTP. Jakarta : Depdikbud

Purwanto, N 1988. Prinsip-prinsip dan Teknis Evaluasi Pengajaran. Bandung, Remaja Rosda karya

Susilo, Herawati 2009. Strategi-strategi Pembelajaran untuk Penelitian Tindakan Kelas. Malang Surya Pena Gemilang

Hadi, Sutrisno 1982. Metodologi Research, jilid I. Yogyakarta: YP. Fak. Psikologi UGM

Kemis, S dan Mc. Taggart, R. 1988. The Action Researh Planner. Victoria Diarcin University Press

Rustiyah, N.K. 1991. Strategi Belajar Mengajar. Jakarta : Bina Aksara.

Slameto, 1988. Evaluasi Pendidikan. Jakarta : Bina Aksara.

Djamarah, Syaiful Bahri. 2002. Strategi Belajar Mengajar. Jakarta : Rineksa Cipta.

Margono. 1997. Meteodologi Penelitian Pendidikan. Jakarta. Rineksa Cipta.
Soekmoto, toeti. 1997. Teori Belajar dan Model Pembelajaran. Jakarta : PauPPAI, Universitas Terbuka.

Arikunto, Suharsimi. 2001. Dasar-dasar Evaluasi Pendidikan. Jakarta: Bina Aksara.

Arikunto, Suharsimi. 1989. Penilaian Program Pendidikan. Proyek Pengembangan LPTK Depdikbud. Dirjen Dikti.

Hasibuan, J.J. dan Moerdjiono. 1998. Proses Belajar Mengajar. Bandung : Remaja Rosdakarya

Usman, Moh. Uzer. 2001. Menjadi Guru Profesional. Bandung : Remaja Rosdakarya. 